\title{
The Effect of Scoliosis Orthosis on the Reduction of Cobb Angle in Scoliosis Patients: A Meta-Analysis
}

\author{
Dody Suprayogi'), Agus Kristiyanto²), Hanung Prasetya3) \\ 1)Masters Program in Public Health, Universitas Sebelas Maret, \\ ${ }^{2)}$ Study Program of Sport Science, Universitas Sebelas Maret \\ 3)Study Program of Acupunture, School of Health Polytechnics, Ministry of Health, Surakarta
}

Background: Scoliosis is a spinal deformity that often occurs in adolescents with a prevalence of $0.47 \%-5.2 \%$ worldwide. The prevalence of scoliosis in Asia was about 2.25\% of the population. In Surabaya, Indonesia, $6.37 \%$ of students from 784 schools who conducted scoliosis screening tests positively had scoliosis. In addition, 9 out of 300 students in Surakarta positively had scoliosis. This study aimed to estimate the effect of using scoliosis orthosis in reducingcobb angle in scoliosis patients by conducting a meta-analysis on theseveral similar articles.

Subjects and Method: This study used a meta-analysis by systematically reviewing the several similar articles from PubMed, ScienceDirect, and Google Scholar. The keywords were "scoliosis" AND "scoliosis orthosis" OR "scoliosis brace" AND "cobb angle" OR "curve" AND "randomized control trial". The intervention was the use of a scoliosis orthosis with a comparison of non-scoliosis orthosis and the scoliosis patients as the study subjects. The outcome of the study was a reduction of cobb angle. The included articles were full-text articles with a randomized controlled trial design that showed the effect size (mean and standard deviations). The articles were collected using PRISMA flow diagrams and analyzed using the Review Manager 5.3 application.

Results: Based on a meta-analysis result of 9 randomized controlled trial articles from the United States, Canada, Germany, Sweden, Denmark, Poland, and Hong Kong, scoliosis orthosis reduced cobb angle in scoliosis patients $(\mathrm{SMD}=-0.67 ; 95 \% \mathrm{CI}=-1.02$ to $-0.33 ; \mathrm{p}$ $<0.001)$. The heterogeneity $\mathrm{I}^{2}=75 \%$.

Conclusion: Scoliosis orthosis affects the reduction of cobb angle in scoliosis patients.

Keywords: scoliosis, cobb angle, scoliosis orthosis

\section{Correspondence:}

Dody Suprayogi. Masters Program in Public Health. Universitas Sebelas Maret, Jl. Ir. Sutami 36A, Surakarta 57126, Central Java, Indonesia. Email: 23dhodik.yogi@gmail.com. Mobile: 08562772052.

\section{Cite this as:}

Suprayogi D, Kristiyanto A, Prasetya H (2020). The Effect of Scoliosis Orthosis on the Reduction of Cobb Angle in Scoliosis Patients: A Meta-Analysis. Indones J Med. 05(04): 356-368. https://doi.org/10.26911/theijmed.2020.05.04.11.

cC (i) (-) Indonesian Journal of Medicine is licensed under a Creative Commons

EY NC SA Attribution-NonCommercial-ShareAlike 4.o International License.

\section{BACKGROUND}

Scoliosis is a spinal deformity characterized by lateral curvature followed by rotation. In general, scoliosis occurs in children or adolescents. Several factors are affecting the occurrence and development of scoliosis in adolescence, especially infemales. Factors that can be used to assess the development of scoliosis in adolescence are growth potential, skeletal maturity, curve size, and curve location (Pelealu et al., 2014).

Scoliosis is a spinal deformity that often occurs in adolescents with a prevalence of $0.47 \%-5.2 \%$ worldwide (Konieczny, 2013). The prevalence of scoliosis in Malaysia, Asia, was about $2.25 \%$ of the population 
(Deepak et al., 2017). In Surabaya, Indonesia, $6.37 \%$ of students from 784 schools who conducted scoliosis screening tests positively had scoliosis (Suryaningrat et al., 2017). In Surakarta, 9 out of 300 students in Surabaya positively had scoliosis (Diana, 2017).

Scoliosis is mostly experienced in children aged 10-16 years. There is the same ratio of adolescent females and males with small curves under $10^{\circ}$. The progression of increasing cobb angle of scoliosis that occurs in adolescent females is faster than in adolescent males. Therefore, adolescent females need more medical intervention. The prevalence of cobb angle greater than $30^{\circ}$ was about $0.2 \%$. In addition, the prevalence of cobb angle greater than $40^{\circ}$ was around 0.1\% (Harawy et al., 2019).

In adolescent female with scoliosis, the risk of progression with a cobb angle of $20^{\circ}-29^{\circ}$ at the thoracic level and skeletal maturity of $0-1$ was $68 \%$. It decreased by $23 \%$ when the patient had 2 to 4 skeletal maturity. Cobb angle/scoliosis curve with the peak curve above the thoraciclevel of 12 had a higher risk in progressivity than scoliosis curve which had the peak curve at the lumbar level (Kuroki, 2018). Curve at the thoracic level that was greater than $50^{\circ}$ and curve at the lumbar level that was greater than $30^{\circ}$ could increase by $1^{\circ}$ each year (Weinstein et al., 2013).

6 to 12 months before period is the peak bone growth in adolescent females. In adolescent males, bone growth correlates with cartilage closure. The degree of scoliosis curve/cobb angle in scoliosis patients can increase and develop more in adulthood. The progression of the cobb angle will increase more if there is no medical treatment. $15 \%-20 \%$ of the initial causes of scoliosis were not found. In addition, 80\% of the causes of structural scoliosis were not found. It often occurred in children or adolescents (Weinstein et al., 2013).

The aetiology, prognosis, and medical interventions in the scoliosis management may vary. However, scoliosis without therapy or intervention causes back pain in patients, especially at peak of the scoliosis curve followed by balance disorders, respiratory system problems, emotional and behavioral disorders, and problems in daily life activities. The most common symptom of scoliosis is an abnormal curvature of the back. It causes pain, decreased quality of life and disability, cosmetically disruptive deformities, functional impairments, lung problems, possible progression in adults, and psychological disorders (Pelealu et al., 2014).

Several previous studies showed that the use of scoliosis orthosis in scoliosis patients could prevent the progression of the scoliosis curve and reduce the scoliosis curve/cobb angle compared to scoliosis patients who did not use scoliosis orthosis.

According to Aulisa et al., (2019), there was an effect of using a scoliosis orthosis with the Lyon brace design in scoliosis patients on the decrease of scoliosis curve/cobb angle. 60 out of 69 patients showed a decrease in cobb angle using the Lyon brace. Therefore, it encouraged the author to conduct a systematic review and a meta-analysis of the study involving the effectiveness of using scoliosis orthosis to reduce the scoliosis curve/cobb angle in scoliosis patients.

\section{SUBJECTS AND METHOD}

\section{Study Design}

This study was a systematic and meta analysis study. The included articles were obtained from several databases such as PubMed, ScienceDirect, and Google Scholar. The keywords were "scoliosis" AND "scoliosis orthosis" OR "scoliosis brace" 
AND "cobb angle" OR "curve" AND "randomized controlled trial".

\section{Inclusion Criteria}

Theincluded articles were full-text articles with a randomized controlled trial (RCT). The intervention was the use of a scoliosis orthosis with a comparison of non-scoliosis orthosis. The study subjects were scoliosis patients. The outcome was a cobb angle with articles whose study was conducted around the world. The cobb angle was $<50^{\circ}$.

\section{Exclusion Criteria}

The excluded articles were articles with meta-analysis, non-English articles, and published before 1990.

\section{Operational Definition of Variables}

The article search was carried out by considering the eligibility criteria defined using the PICO model. The population was scoliosis patients. The intervention was the use of scoliosis orthosis. The comparison was non-scoliosis orthosis. The outcome was the reduction of cobb angle.
Cobb angle was the spinal inclination angle in people with scoliosis as measured from the top and bottom of the vertebrae that formed scoliosis curve. The instrument was X-ray with a continuous measurement scale.

Scoliosis orthosis was a tool used outside the body. It aimed to correct the spinal inclination angle. Instrument: medical records with categorical measurement scale.

\section{Data Analysis}

The data were processed using Review Manager (RevMan 5.3) by calculating the standardized mean difference to determine the study model that was combined and formed the final result of a meta-analysis.

\section{RESULTS}

\section{Article selection}

The articles that were searched using the database with PRISMA flow diagram is in Figure 1. The map of the study area is in Figure 2.

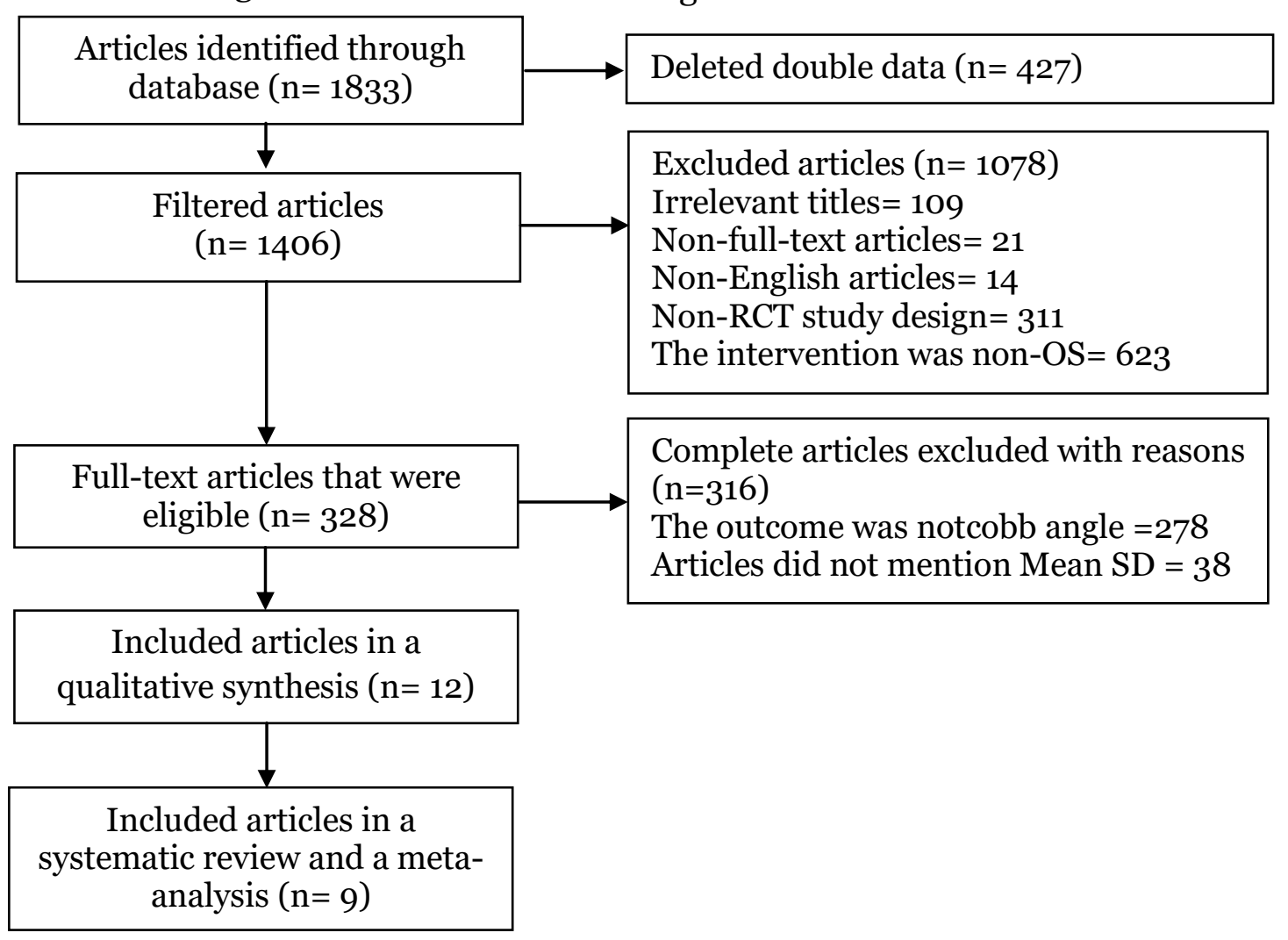

Figure 1. PRISMA flow diagram 


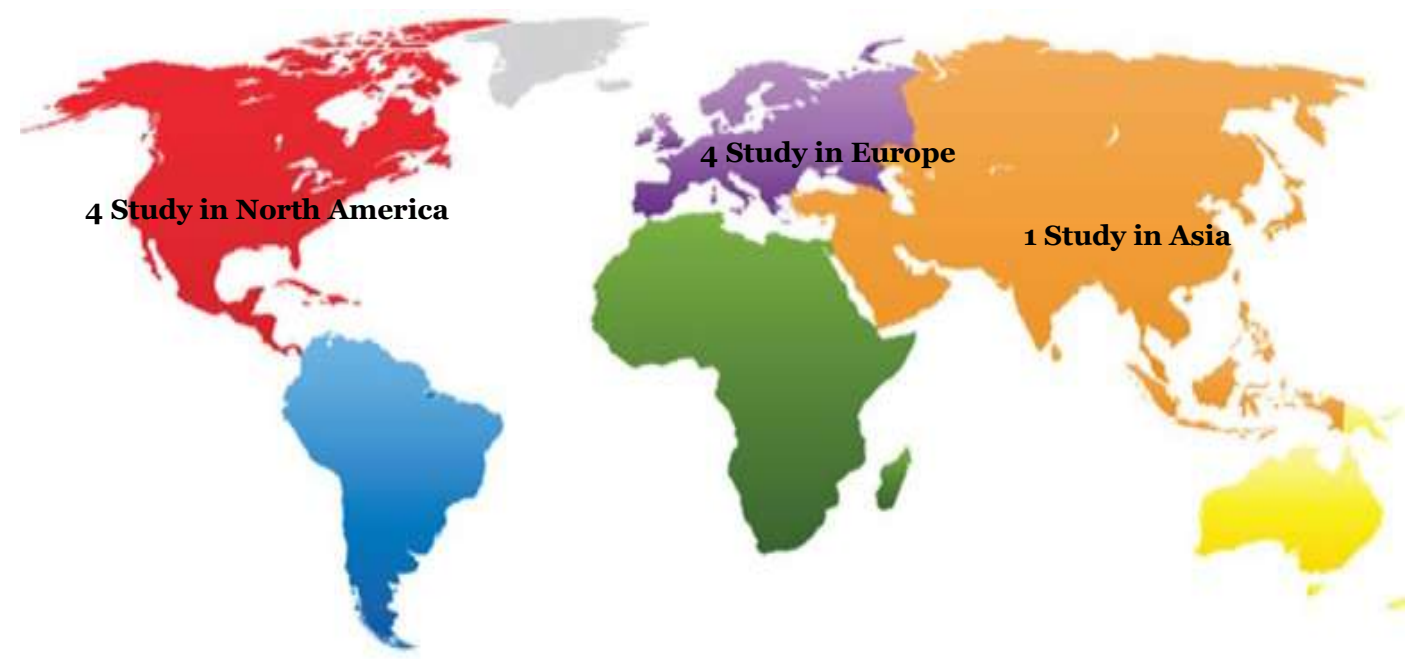

Figure 2. Map of the study area of the effect of usingscoliosis orthosis in reducing cobb angle in scoliosis patients

\section{Forest Plot}

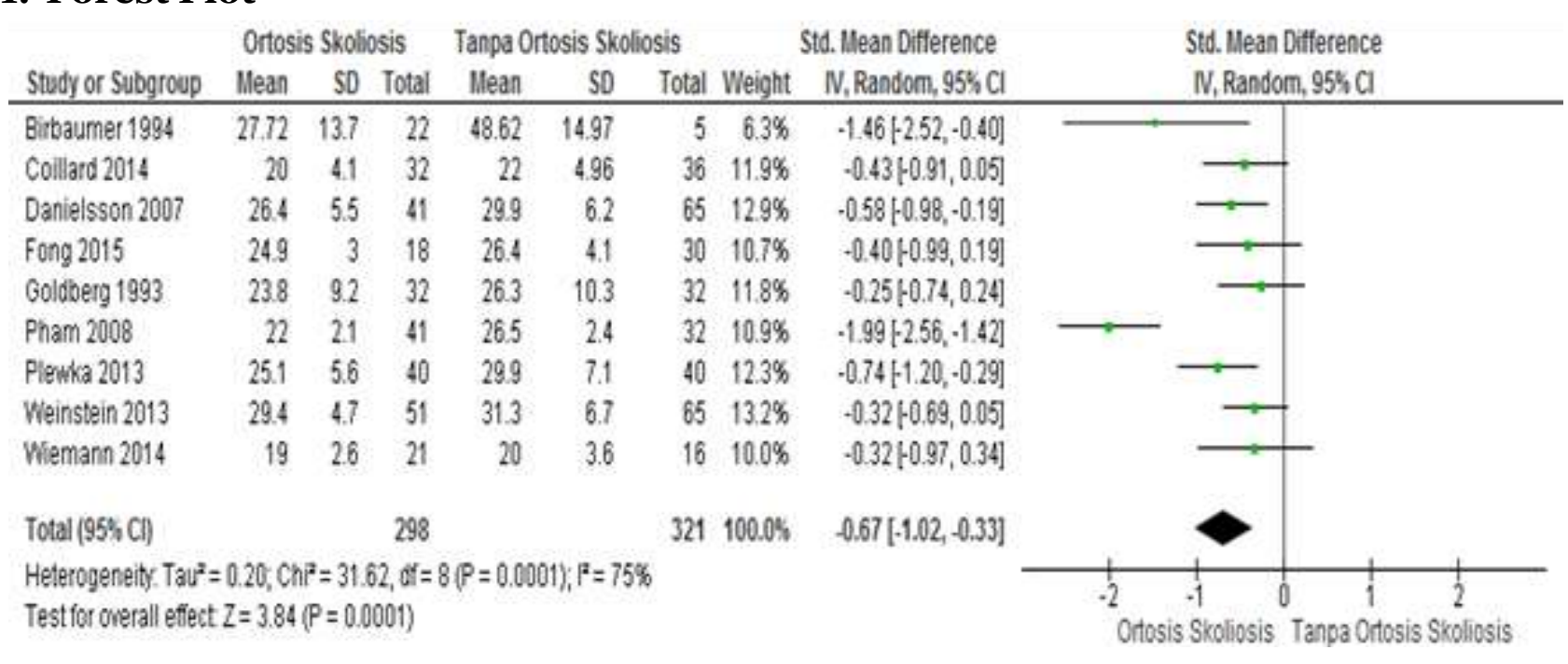

\section{Figure 3. The forest plot of the effect of using scoliosis orthosis in reducing cobb angle in scoliosis patients}

Based on the results of the forest plot (Figure 3), the use of scoliosis orthosis was -0.67 times reduced cobb angle in scoliosis patients compared to non-scoliosis orthosis. The result was statistically significant $(\mathrm{p}<0.001)$. The heterogeneity of the data was $\mathrm{I}^{2}=75 \%$ so that the distribution of the data was heterogeneous (random effect model).

The funnel plot (Figure 3) showed a publication bias. It was characterized by asymmetry of the right and left plots, with 6 plots on the right and 3 plots on the left. The plot on the left of the graph had a standard error between 0.2 and o.6. In addition, the plot on the right had a standard error between 0 and 0.4. Bias also occurred from the imbalance between the distances between studies, both the right and left of the funnel plot. 
Suprayogi et al./ Scoliosis Orthosis to Reduce Cobb Angle

2. Funnel Plot

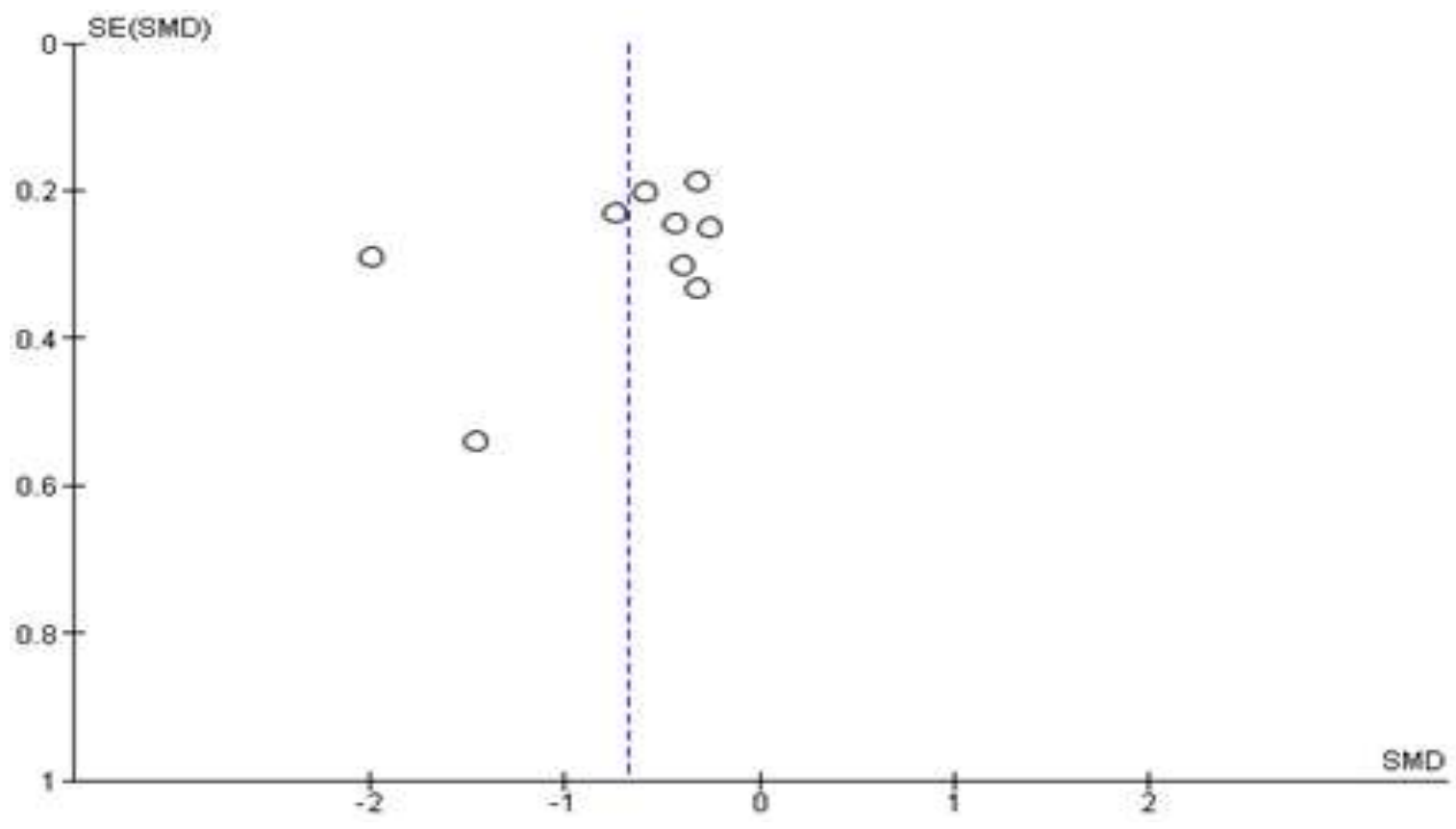

Figure 4. The funnel plotof the effect of using scoliosis orthosis in reducing cobb angle in scoliosis patients 
Table 1. The assessment of the study quality

\section{Checklist Questions}

Did this study discuss a clear study focus?

Was the randomized controlled trial study method suitable for answering study questions?

Were there enough study subjects to establish that the findings were not made by chance?

Were the subjects randomly allocated to the experimental and control groups? If not, could this be biased?

Were the inclusion/exclusion criteria used?

Were the two groups comparable at the beginning of this study?

Were objective and unbiased outcome criteria used?

Were objective and validated measurement methods used to measure the results? If not, were the results scored by someone who did not know the group assignment (i.e. was blinding done on the assessment)?

Was the effect size practically relevant?

How precise was the estimated effect? Was there a confidence interval?

Could there be confounding factors that have not been considered?

Were the results applicable to your study?

Total

Note: $\mathrm{Yes}=1, \mathrm{No}=\mathrm{O}$
Publication Author and Year

\begin{tabular}{cccc}
$\begin{array}{c}\text { Birbaumer et } \\
\text { al. (1994) }\end{array}$ & $\begin{array}{c}\text { Coillard et al. } \\
\text { (2011) }\end{array}$ & $\begin{array}{c}\text { Danielsson et } \\
\text { al. (2007) }\end{array}$ & $\begin{array}{c}\text { Fong et al. } \\
\text { (2015) }\end{array}$ \\
\hline 1 & 1 & 1 & 1 \\
1 & 1 & 1 & 1 \\
1 & 1 & 1 & 1 \\
1 & 1 & 1 & 1 \\
1 & & & 1 \\
1 & 1 & 1 & 1 \\
1 & 1 & 1 & 1 \\
1 & 1 & 1 & 1 \\
1 & 1 & 1 & 1 \\
1 & & & 1 \\
1 & 1 & & 1 \\
12 & 1 & 1 & 1 \\
\hline
\end{tabular}

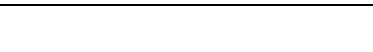


Table 2. The assessment of the study quality

\section{Checklist Questions}

Publication

Author and Year

\begin{tabular}{|c|c|c|c|c|c|}
\hline Checklist Questions & $\begin{array}{l}\text { Goldberg et } \\
\text { al. (1993) }\end{array}$ & $\begin{array}{l}\text { Pham et al. } \\
\quad(2008)\end{array}$ & $\begin{array}{l}\text { Plewka et } \\
\text { al. (2013) }\end{array}$ & $\begin{array}{c}\text { Weinstein } \\
\text { et al. (2013) }\end{array}$ & $\begin{array}{l}\text { Weimann et } \\
\text { al. (2014) }\end{array}$ \\
\hline Did this study discuss a clear study focus? & 1 & 1 & 1 & 1 & 1 \\
\hline $\begin{array}{l}\text { Was the randomized controlled trial study method suitable } \\
\text { for answering study questions? }\end{array}$ & 1 & 1 & 1 & 1 & 1 \\
\hline $\begin{array}{l}\text { Were there enough study subjects to establish that the } \\
\text { findings were not made by chance? }\end{array}$ & 1 & 1 & 1 & 1 & 1 \\
\hline $\begin{array}{l}\text { Were the subjects randomly allocated to the experimental and } \\
\text { control groups? If not, could this be biased? }\end{array}$ & 1 & 1 & 1 & 1 & 1 \\
\hline Were the inclusion/exclusion criteria used? & 1 & 1 & 1 & 1 & 1 \\
\hline $\begin{array}{l}\text { Were the two groups comparable at the beginning of this } \\
\text { study? }\end{array}$ & 1 & 1 & 1 & 1 & 1 \\
\hline Were objective and unbiased outcome criteria used? & 1 & 1 & 1 & 1 & 1 \\
\hline $\begin{array}{l}\text { Were objective and validated measurement methods used to } \\
\text { measure the results? If not, were the results scored by } \\
\text { someone who did not know the group assignment (i.e. was } \\
\text { blinding done on the assessment)? }\end{array}$ & 1 & 1 & 1 & 1 & 1 \\
\hline Was the effect size practically relevant? & 1 & 1 & 1 & 1 & 1 \\
\hline $\begin{array}{l}\text { How precise was the estimated effect? Was there a confidence } \\
\text { interval? }\end{array}$ & 1 & 1 & 1 & 1 & 1 \\
\hline $\begin{array}{l}\text { Could there be confounding factors that have not been } \\
\text { considered? }\end{array}$ & 1 & 1 & 1 & 1 & 1 \\
\hline Were the results applicable to your study? & 1 & 1 & 1 & 1 & 1 \\
\hline Total & 12 & 12 & 12 & 12 & 12 \\
\hline
\end{tabular}

Note: $\mathrm{Yes}=1, \mathrm{No}=\mathrm{O}$ 
Table 3. The description of the primary study included in the meta-analysis

\begin{tabular}{|c|c|c|c|c|c|c|c|}
\hline $\begin{array}{c}\text { Author } \\
\text { (year) }\end{array}$ & Country & $\begin{array}{l}\text { Study } \\
\text { design }\end{array}$ & Sample & $\mathbf{P}$ & $\mathbf{I}$ & $\mathbf{C}$ & $\mathbf{O}$ \\
\hline $\begin{array}{l}\text { Birbaumer et } \\
\text { al. (1994). }\end{array}$ & Germany. & $\begin{array}{c}\text { Randomized } \\
\text { Controlled } \\
\text { Trial. }\end{array}$ & $\begin{array}{l}\text { Scoliosis } \\
\text { orthosis: } 22 \\
\text { Non-scoliosis } \\
\text { orthosis: } 5 \\
\text { Total : } 27\end{array}$ & $\begin{array}{l}\text { Scoliosis } \\
\text { patients aged } \\
\text { 10-14 years } \\
\text { Cobb angle: } \\
150-380\end{array}$ & $\begin{array}{l}\text { Seeing the effect of using } \\
\text { scoliosis orthosis in scoliosis } \\
\text { patients, cobb angle was } \\
\text { measured after } 4-6 \text { months of } \\
\text { orthotic scoliosis use and } 20 \\
\text { hours daily use. }\end{array}$ & $\begin{array}{l}\text { Seeing the progress } \\
\text { of the curve of the } \\
\text { scoliosis patients } \\
\text { without using } \\
\text { scoliosis orthosis }\end{array}$ & $\begin{array}{l}\text { Cobb angle/ } \\
\text { scoliosis } \\
\text { curve }\end{array}$ \\
\hline $\begin{array}{l}\text { Coillard et al. } \\
\text { (2014). }\end{array}$ & Canada & $\begin{array}{c}\text { Randomized } \\
\text { Controlled } \\
\text { Trial. }\end{array}$ & $\begin{array}{l}\text { Scoliosis } \\
\text { orthosis: } 32 \\
\text { Non-scoliosis } \\
\text { orthosis: } 36\end{array}$ & $\begin{array}{l}\text { Scoliosis } \\
\text { patients aged } \\
10-14 \text { years } \\
\text { Cobb angle: } \\
\text { 150-300 } \\
\text { Riser sign : 0-2 }\end{array}$ & $\begin{array}{l}\text { Seeing the effect of using } \\
\text { scoliosis orthosis in scoliosis } \\
\text { patients, the cobb angle was } \\
\text { measured after } 5 \text { years of } \\
\text { using scoliosis orthosis. }\end{array}$ & $\begin{array}{l}\text { Seeing the progress } \\
\text { of the curve of the } \\
\text { scoliosis patients } \\
\text { without using } \\
\text { scoliosis orthosis }\end{array}$ & $\begin{array}{l}\text { Cobb angle/ } \\
\text { scoliosis } \\
\text { curve }\end{array}$ \\
\hline $\begin{array}{l}\text { Danielsson et } \\
\text { al. (2007). }\end{array}$ & Sweden & $\begin{array}{c}\text { Randomized } \\
\text { Controlled } \\
\text { Trial. }\end{array}$ & $\begin{array}{l}\text { Scoliosis } \\
\text { orthosis: } 41 \\
\text { Non-scoliosis } \\
\text { orthosis: } 65 \\
\text { Total : } 106\end{array}$ & $\begin{array}{l}\text { Scoliosis } \\
\text { patients aged } \\
10-15 \text { years } \\
\text { Cobb angle : } \\
250-350 \\
\text { Riser sign : o-4 }\end{array}$ & $\begin{array}{l}\text { Seeing the effects of using } \\
\text { scoliosis orthosis in scoliosis } \\
\text { patients, }\end{array}$ & $\begin{array}{l}\text { Seeing the progress } \\
\text { of the curve of the } \\
\text { scoliosis patients } \\
\text { without using } \\
\text { scoliosis orthosis }\end{array}$ & $\begin{array}{l}\text { Cobb angle/ } \\
\text { scoliosis } \\
\text { curve }\end{array}$ \\
\hline $\begin{array}{l}\text { Fong et al. } \\
\text { (2015). }\end{array}$ & China & $\begin{array}{c}\text { Randomized } \\
\text { Controlled } \\
\text { Trial. }\end{array}$ & $\begin{array}{l}\text { Scoliosis } \\
\text { orthosis: } 18 \\
\text { Non-scoliosis } \\
\text { orthosis: } 31 \\
\text { Total : } 49\end{array}$ & $\begin{array}{l}\text { Scoliosis } \\
\text { patients aged } \\
10-15 \text { years } \\
\text { Cobb angle : } \\
200-300\end{array}$ & $\begin{array}{l}\text { Seeing the effect of using } \\
\text { scoliosis orthosis in scoliosis } \\
\text { patients, the cobb angle was } \\
\text { measured after } 12 \text { months of } \\
\text { using scoliosis orthosis. }\end{array}$ & $\begin{array}{l}\text { Seeing the progress } \\
\text { of the curve of the } \\
\text { scoliosis patients } \\
\text { without using } \\
\text { scoliosis orthosis }\end{array}$ & $\begin{array}{l}\text { Cobb angle/ } \\
\text { scoliosis } \\
\text { curve }\end{array}$ \\
\hline $\begin{array}{l}\text { Golberg et al. } \\
\text { (1993). }\end{array}$ & USA & $\begin{array}{c}\text { Randomized } \\
\text { Controlled } \\
\text { Trial. }\end{array}$ & $\begin{array}{l}\text { Scoliosis } \\
\text { orthosis: } 32 \\
\text { Non-scoliosis } \\
\text { orthosis: } 32 \\
\text { Total : } 64\end{array}$ & $\begin{array}{l}\text { Scoliosis } \\
\text { patients aged } \\
11-15 \text { years. } \\
\text { Cobb angle : } \\
150-350 .\end{array}$ & $\begin{array}{l}\text { Seeing the effect of using a } \\
\text { scoliosis orthosis (Boston } \\
\text { brace) in scoliosis patients, } \\
\text { the cobb angle was measured } \\
\text { after } 12 \text { months of using } \\
\text { scoliosis orthosis }\end{array}$ & $\begin{array}{l}\text { Seeing the progress } \\
\text { of the curve of the } \\
\text { scoliosis patients } \\
\text { without using } \\
\text { scoliosis orthosis }\end{array}$ & $\begin{array}{l}\text { Cobb angle/ } \\
\text { scoliosis } \\
\text { curve }\end{array}$ \\
\hline Pham et al. & Denmark & Randomized & Scoliosis & Scoliosis & Seeing the effect of using a & Seeing the progress & Cobb angle/ \\
\hline
\end{tabular}




\begin{tabular}{|c|c|c|c|c|c|c|c|}
\hline (2008). & & $\begin{array}{l}\text { Controlled } \\
\text { Trial. }\end{array}$ & $\begin{array}{l}\text { orthosis: } 41 \\
\text { Non-scoliosis } \\
\text { orthosis: } 32 \\
\text { Total : } 73\end{array}$ & $\begin{array}{l}\text { patients aged } \\
11-15 \text { years } \\
\text { Cobb angle : } \\
\text { 200-300. } \\
\text { Riser sign: 0-3 }\end{array}$ & $\begin{array}{l}\text { scoliosis orthosis (Cheneau } \\
\text { Brace) in scoliosis patients, } \\
\text { the cobb angle was measured } \\
\text { after 6-12 months of using } \\
\text { scoliosis orthosis. }\end{array}$ & $\begin{array}{l}\text { of the curve of the } \\
\text { scoliosis patients } \\
\text { without using } \\
\text { scoliosis orthosis }\end{array}$ & $\begin{array}{l}\text { scoliosis } \\
\text { curve }\end{array}$ \\
\hline $\begin{array}{l}\text { Plewka et al. } \\
\text { (2013). }\end{array}$ & Poland & $\begin{array}{c}\text { Randomized } \\
\text { Controlled } \\
\text { Trial. }\end{array}$ & $\begin{array}{l}\text { Scoliosis } \\
\text { orthosis: } 40 \\
\text { Non-scoliosis } \\
\text { orthosis: } 40 \\
\text { Total : } 80\end{array}$ & $\begin{array}{l}\text { The average of } \\
\text { scoliosis } \\
\text { patients aged } \\
12 \text { years } \\
\text { Cobb angle: } \\
\text { 150-500. } \\
\text { Riser sign: 0-3 }\end{array}$ & $\begin{array}{l}\text { Seeing the effect of using } \\
\text { scoliosis orthosis (SpineCor) } \\
\text { in scoliosis patients, the cobb } \\
\text { angle was measured after } 24 \\
\text { months of orthotic scoliosis } \\
\text { use and } 20 \text { hours daily use. }\end{array}$ & $\begin{array}{l}\text { Seeing the progress } \\
\text { of the curve of the } \\
\text { scoliosis patients } \\
\text { without using } \\
\text { scoliosis orthosis }\end{array}$ & $\begin{array}{l}\text { Cobb angle/ } \\
\text { scoliosis } \\
\text { curve }\end{array}$ \\
\hline $\begin{array}{l}\text { Weinstein et } \\
\text { al. (2013) }\end{array}$ & USA & $\begin{array}{c}\text { Randomized } \\
\text { Controlled } \\
\text { Trial. }\end{array}$ & $\begin{array}{l}\text { Scoliosis } \\
\text { orthosis: } 52 \\
\text { Non-scoliosis } \\
\text { orthosis: } 65 \\
\text { Total : } 117\end{array}$ & $\begin{array}{l}\text { Scoliosis } \\
\text { patients aged } \\
10-15 \text { years } \\
\text { Cobb angle : } \\
\text { 200-400. } \\
\text { Riser sign: } 0-5\end{array}$ & $\begin{array}{l}\text { Seeing the effect of using } \\
\text { scoliosis orthosis in scoliosis } \\
\text { patients, the cobb angle was } \\
\text { measured after } 6 \text { months of } \\
\text { scoliosis orthosis use and } 18 \\
\text { hours daily use. }\end{array}$ & $\begin{array}{l}\text { Seeing the progress } \\
\text { of the curve of the } \\
\text { scoliosis patients } \\
\text { without using } \\
\text { scoliosis orthosis }\end{array}$ & $\begin{array}{l}\text { Cobb angle/ } \\
\text { scoliosis } \\
\text { curve }\end{array}$ \\
\hline $\begin{array}{l}\text { Wiemann et } \\
\text { al. (2014). }\end{array}$ & USA & $\begin{array}{c}\text { Randomized } \\
\text { Controlled } \\
\text { Trial. }\end{array}$ & $\begin{array}{l}\text { Scoliosis } \\
\text { orthosis: } 21 \\
\text { Non-scoliosis } \\
\text { orthosis: } 16 \\
\text { Total : } 37\end{array}$ & $\begin{array}{l}\text { Scoliosis pati- } \\
\text { ents aged } 11- \\
15 \text { years } \\
\text { Cobb angle: } \\
\text { 150-250 } \\
\text { Riser sign: 0-2 }\end{array}$ & $\begin{array}{l}\text { Seeing the effect of using } \\
\text { scoliosis orthosis in scoliosis } \\
\text { patients, the cobb angle was } \\
\text { measured after } 6 \text { months of } \\
\text { using scoliosis orthosis }\end{array}$ & $\begin{array}{l}\text { Seeing the progress } \\
\text { of the curve of the } \\
\text { scoliosis patients } \\
\text { without using } \\
\text { scoliosis orthosis }\end{array}$ & $\begin{array}{l}\text { Cobb angle/ } \\
\text { scoliosis } \\
\text { curve }\end{array}$ \\
\hline
\end{tabular}




\section{DISCUSSION}

This systematic review and a meta-analysis study discussed the effect of using scoliosis orthosis on the reduction of cobb angle in scoliosis patients. This study discussed the data on the cobb angle which was considered important due to the effects that came out if further treatment was not given immediately. This systematic study and a meta-analysis study used studies that have controlled for confounding factors. It could be seen from the inclusion criteria.

The estimation of the combined effect of scoliosis orthosis in scoliosis patients was processed using RevMan 5.3 with the continuous method. It aimed to analyze the effect size or standardized mean difference in two groups of bivariate data that had been controlled for confounding factors by randomization. The results of the systematic study and a meta-analysis were in the form of a forest plot and a funnel plot. The forest plot showed an overview of information from each of the studies examined in the meta-analysis and the estimation of the overall results. The forest plot showed visually the amount of variation (heterogeneity) among study results (Murti, 2018).

Scoliosis was a spinal curvature to the lateral >10 degrees. Scoliosis was a spinal disorder that made the spine to bend to the left or right side. It was crooked and protruded. It could be seen clearly from the back. This disease was also difficult to recognize unless the patients grew up (Putra and Trifani, 2020).

$80 \%$ of scoliosis cases in the world were idiopathic. The prevalence of diopathic scoliosis with a curve of more than 10 degrees was 0.5-3 per 100 children and adolescents. The prevalence on a curve of more than 30 degrees was $1.5-3$ per 1000 population. Around $4 \%$ of all children aged 10-14 years had scoliosis. $40-60 \%$ of them were female. Scoliosis was more common occurred twice in adolescent females than adolescent males (Putra and Trifani, 2020).

One of the interventions for scoliosis patients was scoliosis orthosis. The use of scoliosis orthosis in scoliosis patients aimed to control the spinal curvature until the bone was permanently mature. The use of scoliosis orthosis was an effort to modify the mechanical shape and control the development of curves in the spinal curvature by applying certain pressure points to the torso (Kuroki, 2018).

Scoliosis orthosis could prevent progressivity and reduce the degree of cobb angle in scoliosis patients because the correction system used a 3 point pressure mechanism. The 3 point pressure mechanism worked by applying pressure to the peak of the spinal curve that was crooked according to the patient's needs and ability to endure pain. To get maximum results, scoliosis patients must adhere to use a scoliosis orthosis for 8-23 hours every day (Lusini et al., 2014).

The results of a meta-analysis of 9 articles regarding the effect of using scoliosis orthosis on reducing cobb angle in scoliosis patients were summarized in a forest plot. The forest plot in Figure 3 shows that scoliosis orthosis reduced -0.67 times the degree of cobb angle compared to non-scoliosis orthosis (SMD=-0.67; $95 \% \mathrm{CI}=-1.02$ to $-0.33 ; \mathrm{p}<0.001)$. The heterogeneity of the data showed that I $2=75 \%$. It indicated a heterogeneous distribution of the data. Therefore, the analysis used a random effect model.

Based on the result of this study, scoliosis orthosis can reduce the cobb angle in scoliosis patients and it is statistically significant. 


\section{AUTHOR CONTRIBUTION}

DodySuprayogi was the main researcher who selected the topic, explored, and collected the data. AgusKristiyanto and HanungPrasetya played a role in analyzing the data and reviewing the documents.

\section{CONFLICT OF INTEREST}

This study did not have conflict of interest.

\section{FUNDING AND SPONSORSHIP}

This study used funds from the main researcher.

\section{ACKNOWLEDGEMENT}

We would like to thank the database provider such as PubMed, Google Scholar dan Science Direct.

\section{REFERENCE}

Aulisa AG, Guzzanti V, Falciglia F, Giordano F, Marzetti E, Aulisa L (2015). Lyon bracing in adolescent females with thoracic idiopathic Skoliosis: a prospective study based on srs and sosort criteria, BMC Musculoskelet Disord, 16 (316), doi: 10.1186/s12891015-0782-0.

Birbaumer N, Flor H, Cevey B, Dworkins B, Miller NE (1994). Behavioral treatment of scoliosis and kyphosis. J Psychosom Res, 38(6): 623-628. doi: https://doi.org/10.1016/0022-3999(94)90060-4.

Coillard C, Circo B, Rivard CH (2014). A prospective randomized controlled trial of the natural history of idiopathic scoliosis versus treatment with the SpineCor brace. Eur J Phys Rehabil Med. 5o(5):479-87.

Danielsson AJ, Hasserius R, Ohlin A, and Nachemson AL (2007). A prospective study of brace treatment versus obser- vation alone in adolescent idiopathic scoliosis. Spine, 32(20):2198-207. doi: 10.1097/BRS.obo13e31814b851f.

Deepak AS, Ong JY, Choon DSK, Lee CK, Chiu CK, Chan CYW, dan Kwan MK, (2017). The clinical effectiveness of school screening programme for idiopathic scoliosis in Malaysia. Malays Orthop J, 11(1): 41-46, doi: 10.5704/MOJ.1703.018.

Diana (2017). Prevalensi kelengkungan skoliosis tipe c dan s siswa sekolah dasar sekolah menengah pertama dan sekolah menengah atas. Jurusan Fisioterapi Fakultas Ilmu kesehatan, Universitas Muhammadiyah Surakarta, Surakarta.

Fong DTP, Pang KY, Chung MML, Hung ASL, Chan KM (2012). Evaluation of combined prescription of rocker sole shoes and custom-made foot orthoses for the treatment of plantar fasciitis. Clin Biomech, 27(1072-1077). https://dx.doi.org/10.1016/j.clinbiomech.2012.08.003.

Goldberg CJ, Dawling FE, Hall JE, Emans JB (1993). A statistical comparison between natural history of idiopathic scoliosis and brace treatment in skeletally immature adolescent girls. Spine,18(7):902-8. doi: 10.1097/ooo07632-199306000-00015.

Goweda, Reda A, et al. (2015). Prevalence and risk factors of plantar fasciitis among patients with heel pain attending primary health care centers of Makkah Kingdom of Saudi Arabia. High Inst. Public Health, 245(2):7175. https://dx.doi.org/10.21608/jhiph.2015.20247.

Hawary RE, Regev DZ, Floman Y, Lonner BS, Alkhalife YI, Betz RR (2019). Brace treatment in adolescent idiopathic Scoliosis: risk factors for failure a literature review. Spine J, 19: 1917- 
1925, https://doi.org/10.1016/j.spinee.2019.07.008.

Konieczny MK, Senyurt H, Krauspe R (2013). Epidemiology of adolescent idiopathic Skoliosis. J Child Orthop, 7(1): 3-9, doi: 10.1007/s11832-0120457-4.

Kuroki H (2018). Brace treatment for adolescent idiopathic scoliosis. J Clin Med, 7 (136). doi:10.3390/jcm7060136.

Lusini M, Donzelli S, Minnella S, Zaina F, Negrini S (2014). Brace treatment is effective in idiopathic scoliosis over $45^{\circ}$ : an observational prospective cohort controlled study. Spine J, 14(9): 1951-6. doi: 10.1016/j.spinee.2013.11.040.

Murti B (2018). Prinsip dan Metode Riset Epidemiologi. Edisi ke 5. Surakarta: Program Studi Ilmu Kesehatan Masyarakat.

Pelealu J, Leonard SA, Engeline A (2014). Rehabilitasi medik pada skoliosis, Jurnal biomedik, 6 (1) : 8-13. Universitas Samratulangi Manado.

Pham VM, Houlliez A, Herbaux B, Schill A, Thevenon A (2008). Determination of the influence of the Cheneau brace on quality of life for adolescent with idiopathic scoliosis. Ann Readapt Med Phys, 51(1):3-8, 9-15. doi: 10.1016/j.annrmp.2007.08.008.

Plewka B, Sibinski M, Synder M, Witonski D, Klimek KK, Plewka M (2013). Radiological evaluation of treatment with SpineCor brace in children with idiopathic spinal scoliosis. Ortop Traumatol Rehabil, 15(3):227-34. doi: 10.5604/15093492.1058414.

Putra RAC, Trifani F (2020). In-Brace Correction (IBC) terhadap tipe dan besaran kurva pada pasien Adolescent Idiopathic Skoliosis (AIS). Jurnal Kesehatan, 14(1). doi: 10.36082/qjk.v14i1.98.

Weinstein SL, Dolan LA, Wright JG, Dobbs MB (2013). Bracing in adolescent with idiopathic skoliosis. N Engl J Med, 369(16): 1512-1521 doi: $10.1056 / \mathrm{N}-$ EJMoa1307337.

Wiemann JM, Shah SA, Price CT (2014). nighttime bracing versus observation for early adolescent idiopathic scoliosis. J Pediatr Orthop, 34(6):603-6. doi: 10.1097/BPO.0000000000000221. 